\title{
PRODUKTIVITAS RUMPUT PAKAN ANOA (Bubalus spp.) SEKITAR PENANGKARAN PADA KONDISI PRA BUDIDAYA
}

\author{
Irawati, D., D. Arini dan A. Mayasari \\ Balai Penelitian dan Pengembangan Lingkungan Hidup dan Kehutanan Manado \\ Email: irawati.diah@gmail.com
}

\begin{abstract}
ABSTRAK
Ketersediaan dan kualitas hijauan yang baik menjadi salah satu pendukung keberhasilan kegiatan penangkaran. Penelitian ini bertujuan untuk mengetahui produktivitas serta kualitas rumput pakan anoa terutama di musim kemarau yang mampu mendukung populasi anoa di penangkaran Anoa Breeding Centre pada kondisi pra budidaya. Penelitian dilaksanakan dienam lokasi yang menjadi tempat pengambilan rumput pakan anoa di sekitar penangkaran yaitu Mapanget, Matungkas dan Kairagi. Metode yang digunakan dalam pengukuran produktivitas adalah dengan membuat plot ukuran 1 x 1 meter dibiarkan selama 20 hari selama tiga kali ulangan untuk dilakukan pemotongan dan penimbangan. Kualitas rumput pakan diketahui dengan melakukan analisis proksimat. Hasil pengukuran di enam lokasi menunjukkan bahwa produktivitas rumput pakan sebesar 34,15 kg/hari, jika konsumsi perhari untuk anoa diperkirakan 5-10 kg/hari maka hanya dapat memenuhi 3-4 ekor anoa. Beberapa alternatif untuk memenuhi kebutuhan pakan anoa dapat dilakukan dengan memberikan tambahan hijauan maupun sayuran serta melalui penanaman rumput unggul di sekitar penangkaran disertai dengan pemupukan dan pemeliharaan yang baik. Berdasarkan kualitasnya diperoleh bahwa rumput pakan yang diberikan pada anoa dapat memenuhi kebutuhan protein anoa sebesar 11-16/100 g setiap harinya. Sedangkan kebutuhan harian kalsium maupun phosphor belum cukup terpenuhi. Sehingga diperlukan pakan tambahan dan mineral yang dapat mencukupi kebutuhan mineral bagi anoa di penangkaran.
\end{abstract}

Kata kunci: Anoa, daya dukung, kualitas, pra budidaya, produktivitas.

\section{PENDAHULUAN}

Anoa (Bubalus spp.) adalah satwa endemik Pulau Sulawesi dan Pulau Buton. Baik anoa dataran tinggi (Bubalus quarlesi) maupun anoa dataran rendah (Bubalus depressicornis) terdaftar sebagai satwa liar terancam punah (Endangeredspecies) berdasarkan daftar merah IUCN (Semiadietal., 2008a, 2008b). Penurunan populasi anoa di habitat alam disebabkan oleh dua factor utama yakni perburuan dan perubahan hutan sebagai habitat anoa. Usaha untuk melestarikan satwa anoa menurut pedoman Rencana Aksi Konservasi Anoa 2013-2022 (Peraturan Menteri Kehutanan No.54 Tahun 2013) dapat dilakukan melalui dua cara yaitu konservasi secara in-situ dan ex-situ. Konservasi insitu yang dilakukan di dalam habitat aslinya melalui pengelolaan habitat yang prinsipnya adalah menjaga habitat yang masih tersisa atau juga dapat dilakukan dengan memperbaiki hutan yang terdegradasi, restorasi ekosistem untuk memulihkan daya dukung habitat termasuk menjaga konektivitas habitat anoa dan mempertahankan keterwakilan setiap populasi/ sub populasi. Konservasi ex-situ dilakukan sebagai upaya untuk memback-up populasi di habitat alam serta berfungsi sebagai gene-bank.

Konservasi ex-situ anoa di Sulawesi saat ini sedang dirintis oleh Balai Penelitian dan Pengembangan
Lingkungan Hidup dan Kehutanan (BP2LHK) Manado bekerjasama dengan Balai Konservasi Sumber daya Alam (BKSDA) Sulawesi Utara dengan membentuk "Anoa BreedingCentre". Sesuai dengan namanya ,Anoa Breeding Centre bertujuan untuk merawat dan memelihara anoa yang telah lama dipelihara oleh masyarakat dan memiliki kemungkinan besar tidak dapat dikembalikan lagi kehabitat alaminya untuk selanjutnya dikembang biakan. Anoa adalah kelompok herbivore ruminansia yaitu satwa liar memamah biak yang makanannya terdiri atas jenis tumbuhan, termasuk daun, semak, herba, dan berbagai jenis rumput di hutan (Mustari\& Masy'ud, 2001) serta berpotensi sebagai satwa penghasil daging (Basri, 2008). Pemanfaatan daging anoa oleh masyarakat terutama yang tinggal di sekitar kawasan hutan merupakan tindakan illegal karena anoa adalah satwa dilindungi di Indonesia maupun internasional. Namun apabila dimasa depan satwa ini berhasil dikembangbiakan dan didomestikasi, selain dapat dimanfaatkan sebagai sumber protein diharapkan juga kelestarian anoa di habitat alamnya dapat terjamin. Proses domestikasi diawali dengan usaha penangkaran.

Saat ini Anoa Breeding Centre memiliki enam ekor anoa yang terdiri dari dua jantan dan betina yang dipelihara dalam kandang secara individu yang 
mengadopsi sifat soliter dari anoa di alam. Pada kondisi pra budidaya maupun pemeliharaan di kebun binatang pada umumnya anoa tidak mengalami kendala dalam hal pemberian pakan, artinya berbagai jenis pakan yang tersedia dapat diberikan pada anoa dan dapat beradaptasi dengan baik. Dalam usaha penangkaran, ketersediaan, keragaman jenis dan kualitas pakan yang baik akan sangat mempengaruhi pertumbuhan maupun reproduksi hewan yang dipelihara dan pada akhirnya adalah keberhasilan dalam bereproduksi. Pakan anoa terdiri atas hijauan sebagai pakan dasar yang kaya serat kasar untuk sumber energy dan tangsal perut dan konsentrat yang kaya akan protein, energi, mineral organik dan vitamin yang diperlukan ternak. Rumput adalah makanan utama bagi anoa di penangkaran disamping jenis hijauan lain yang memiliki kadar atau kandungan tannin rendah (Basri dan Rukmi, 2011). Ketersediaan pakan bagi anoa termasuk rumput dan hijauan lain yang sangat penting terutama jika musim kering tiba, rumput lapangan akan mengalami penurunan produktivitas dan menjadi sulit diperoleh. Tujuan dari penelitian ini adalah untuk mengetahui potensi, kualitas serta produktivitas rumput pakan anoa untuk mendukung populasi anoa yang dipelihara di penangkaran pada kondisi pra budidaya.

\section{METODE PENELITIAN}

\section{Tempat dan Waktu}

Penelitian dilaksanakan di Anoa Breeding Centre BP2LHK Manado dan lokasi-lokasi yang menjadi pengambilan rumput di sekitar penangkaran yaitu Kecamatan Mapanget, Matungkas dan Kairagi. Penelitian dilaksanakan pada bulan AgustusDesember 2015.

\section{Materi dan Alat}

Materi yang digunakan dalam penelitian ini adalah enam ekor anoa di kandang penangkaran Anoa Breeding Centre. Alat yang digunakan terdiri atas timbangan duduk dengan kapasitas 5okg, oven elektrik, pita ukur, kamera, lembar isian data (tally sheet), dan alat tulis menulis.

\section{Prosedur Penelitian}

\section{Pengukuran Produktivitas Pakan}

Produktivitas pakan anoa dihitung melalui pertumbuhan rumput pakan pada petak contoh areal pengambilan pakan anoa. Petak contoh yang dibuat berukuran 1x1 $\mathrm{m}$. Setiap plot dilakukan pemotongan masing-masing jenis tumbuhan pakan dan kemudian dibiarkanselama 20 hari. Setelah 20 hari, kemudian dilakukan pemotongan dan penimbangan kembali dengan cara yang sama sebanyak tiga kali ulangan (Kwatrina et al.,2011).

\section{Kualitas Hijauan Pakan}

Kualitas hijauan pakan diketahui dari nutrisi yang terkandung di dalamnya. Nutrisi diperoleh dari hasil analisis proksimat pada rumput pakan di setiap lokasi pengambilan. Nutrisi yang dianalisis terdiri atas air, protein, lemak, GE, serat kasar, abu, kalsium, posphor. Analisis proksimat dilakukan di Laboratorium Balai Penelitian Ternak Ciawi Bogor.

\section{Analisa Data}

Produktivitas pakan diperoleh dari hasi pemotongan dan penimbangan dari setiap petak contoh yang dipagar dan dikonversi keluas areal secara keseluruhan dengan menggunakan rumus sebagai berikut (Alikodra, 2002).

$$
\frac{P}{L}=\frac{p}{l}
$$

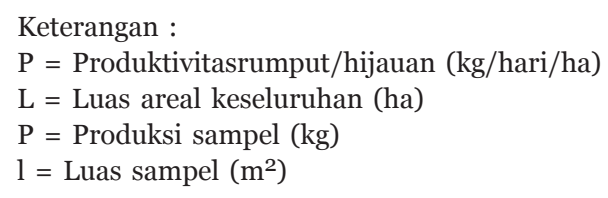

Untuk menghitung daya dukung, rumus yang digunakan adalah sebagai berikut (Susetyo, 1980):

$$
\text { Daya dukung }=\frac{P \times A}{C}
$$

Keterangan

$\mathrm{P}=$ Produktivitasrumput/hijauan $(\mathrm{kg} / \mathrm{hari} / \mathrm{ha})$

$\mathrm{A}=$ Luas permukaan yangditumbuhi rumput (ha)

$\mathrm{C}=$ Kebutuhan makan anoa (kg/ekor/hari).

\section{HASIL DAN PEMBAHASAN}

\section{Produktivitas Rumput Pakan}

Pakan utama anoa di penangkaran adalah jenis rumput lapangan, didominasi oleh rumput australia. Pasokan kebutuhan rumput pakan harian anoa di penangkaran disuplai dari luar dan sekitar penangkaran. Namun pada musim kering rumput di sekitar penangkaran menjadi sulit didapat sehingga hanya mengandalkan rumput dari beberapa lokasinya yang dekat dengan sumber air seperti di Matungkas dan Kairagi.

Kebutuhan pakan anoa dan ternak ruminansia pada umumnya adalah 10\% dari total berat badannya. Berdasarkan hasil pengamatan dengan menggunakan hijauan tunggal yaitu rumput australi menunjukkan kebutuhan yang cukup bervariasi pada anoa di penangkaran yaitu antara 11,26-8,40\% tergantung dari umur dan berat badannya. Anoa di penangkaran rata-rata mengkonsumsi rumput sekitar 5-10 kg/ekor/ hari atau dalam satu hari membutuhkan rumput segar sebanyak 50-60 kg/hari untuk enam ekor 
anoa. Dengan kebutuhan tersebut tentunya sangat diperlukan penyediaan pakan yang cukup dan berkesinambungan. Hasil perhitungan produktivitas pakan disekitar areal penangkaran di enam lokasi disajikan dalam Tabel 1.

Tabel 1. menunjukkan bahwa perhari pada musim kemarau produktivitas rumput pakan anoa di sekitar areal penangkaran hanya 34,15 kg/hari. Jika kebutuhan pakan untuk anoa rata- rata adalah 8-10 kg/hari/anoa, dengan demikian keenam lokasi tersebut hanya bias mendukung sekitar 3-4 ekor anoa sehingga alternatif lain untuk memperoleh hijauan maupun pemberian pakan tambahan yang dapat memenuhi kebutuhan pakan anoa sangat diperlukan.

\section{Kualitas Hijauan Pakan}

Anoa membutuhkan protein pakan yang lebih banyak (Basri et al., 2008). Hal ini dapat dilihat dari postur tubuh anoa yang memiliki otot daging lebih padat dengan tingkat perlemakan tubuh yang rendah (Kasim, 2002). Tingkat perlemakan yang rendah menyebabkan porsi daging pada tulang menjadi tinggi (Rosyidi, 2005). Porsi daging yang tinggi pada tulang dan tingkat perlemakan yang rendah pada anoa memberi petunjuk bahwa anoa sebagai hewan liar menggunakan protein untuk ditransformasi kedalam bentuk daging, tetapi tidak untuk ditimbun dalam bentuk lemak. Pakan yang berkualitas baik akan memiliki tingkat konsumsi yang relatif tinggi bila dibandingkan dengan pakan berkualitas rendah. Kualitas pakan dapat dilihat dari kandungan zat makanan dan palatabilitasnya (Parakkasi, 1999).

Tabel 1. Lokasi dan Produksi Rumput Masing-masing Lokasi

\begin{tabular}{|c|c|c|c|c|c|}
\hline No & Lokasi & Jenis Dominan & $\begin{array}{c}\text { Luas } \\
\text { areal } \\
\text { yang di- } \\
\text { tumbuhi } \\
\text { rumput } \\
\left(\mathrm{m}^{2}\right)\end{array}$ & $\begin{array}{c}\text { Jumlah } \\
\text { plot } \\
\text { contoh }\end{array}$ & $\begin{array}{l}\text { Produk } \\
\text { tivitas } \\
\text { (kg/hari) }\end{array}$ \\
\hline 1. & Matungkas 1 & $\begin{array}{l}\text { Rumput lapangan yang } \\
\text { didominasi jenis rumput } \\
\text { Australi }\end{array}$ & 310 & 16 & 8,14 \\
\hline 2. & Matungkas 2 & $\begin{array}{l}\text { Rumput lapangan yang } \\
\text { didominasi jenis rumput } \\
\text { Australi }\end{array}$ & 160 & 11 & 3,95 \\
\hline 3. & Matungkas 3 & $\begin{array}{l}\text { Rumput lapangan yang } \\
\text { didominasi jenis rumput } \\
\text { Australi }\end{array}$ & 125 & 6 & 2,68 \\
\hline & Kairagi & $\begin{array}{l}\text { Rumput lapangan yang } \\
\text { didominasi jenis rumput } \\
\text { Australi dan gajah }\end{array}$ & 253 & 6 & 6,48 \\
\hline 5. & Matungkas 4 & $\begin{array}{l}\text { Rumput lapangan yang } \\
\text { didominasi jenis rumput } \\
\text { Australi }\end{array}$ & 449 & 8 & 12,84 \\
\hline & Kebun pakan & $\begin{array}{l}\text { Rumput lapangan yang } \\
\text { didominasi jenis rumput } \\
\text { gajah }\end{array}$ & 1050 & 9 & 0,06 \\
\hline \multicolumn{3}{|r|}{ Jumlah } & 2347 & 56 & 34,15 \\
\hline
\end{tabular}

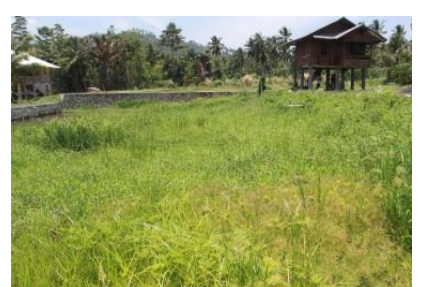

A

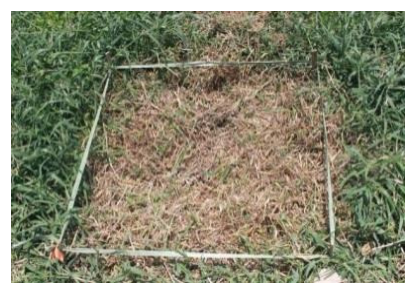

B
Gambar1. (A). Lokasi pengambilan rumput pakan dan (B). Contoh petak ukur

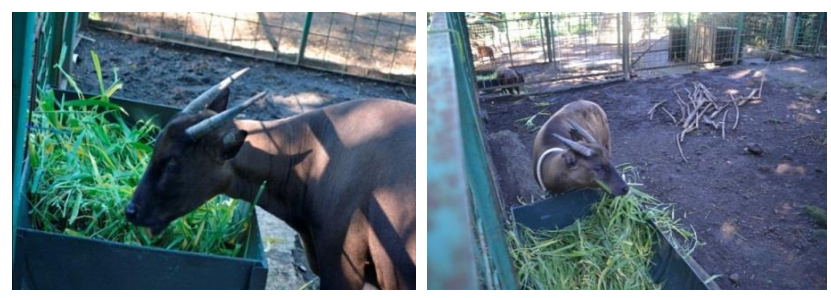

Gambar2. Anoa dikandang Anoa Breeding Centre Manado.

Berdasarkan hasil analisis nutrisi rumput sebagai pakan yang diberikan pada anoa sehari-hari (Tabel2) menunjukkan bahwa rumput australi memiliki kandungan protein yang cukup tinggi sebesar 1116/10og jika dibandingkan dengan jenis rumput pakan ternak lainnya seperti Pennisetum purpurephoides dan Paspalum dilatatum sebesar 10,82\% dan Setaria splendida sebesar 8,40\% (Kushartono dan Iriani, 2004). Sedangkan pada lokasi kebun pakan yang didominasi jenis rumput gajah hanya memiliki kandungan protein sebesar 5,14/100 g. Jika dibandingkan dengan kebutuhan pokok protein untuk anoa dewasa di kandang penangkaran yaitu sebesar 105 g/hari/ekor (Basri et al., 2008), maka jenis rumput australi/lapangan yang diberikan sudah dapat memenuhi kebutuhan protein harian bagi anoa di penangkaran. Begitu pula dengan kebutuhan nutrisi lainnya seperti energy (TDN) anoa membutuhkan $367 \mathrm{~g} /$ hari/ekor. Sedangkan untuk kebutuhan pokok kalsium (Ca) dan Phospor (P) anoa membutuhkan 7,5 g/hari, dan 7,1 g/hari/ekor. Nilai ini lebih besar dari pada jumlah Ca yang dibutuhkan kambing maupun domba yaitu $2 \mathrm{~g}$ /ekor/hari (Basri et al., 2008). Hasil analisis nutrisi pakan juga menunjukkan bahwa kandungan $\mathrm{Ca}$ dan $\mathrm{P}$ dalam rumput pakan masih kurang atau belum mampu memenuhi untuk kecukupan kebutuhan dasar anoa.

Di habit atalaminya, anoa memakan jenis-jenis aquatic feed seperti pakis, rumput, buah-buahan yang jatuh dan umbi-umbian (Pujianingsih et al.,2005). Jika dibandingkan dengan beberapa jenis pakan anoa dihabitat alaminya kandungan nutrisi rumput pakan yang diberikan pada anoa di penangkaran Anoa Breeding Centre tidak berbeda jauh. Misalnya untuk jenis pakan alami seperti rumput Paspalum conjugatum memiliki kandungan nutrisi sebagai berikut protein kasar 9,34/100 g, abu 11,45/100g, 
Tabel 2. Hasil analisis nutrisi rumput pakan anoa setiap lokasi pengambilan

\begin{tabular}{clcccccccc}
\hline \multirow{2}{*}{ No } & \multirow{2}{*}{ Lokasi } & \multicolumn{9}{c}{ Kandungan Nutrisi $(/ 100 \mathrm{~g})$} \\
\cline { 3 - 10 } & & Air & Protein & Lemak & SK & Abu & Ca & P & GE \\
\hline 1. & Matungkas1 & 7,89 & 11,91 & 2,52 & 31,30 & 12,51 & 0,30 & 0,14 & 3684 \\
2. & Matungkas2 & 6,43 & 13,34 & 3,23 & 28,83 & 15,21 & 0,40 & 0,49 & 3700 \\
3. & Matungkas3 & 6,34 & 10,41 & 2,52 & 31,36 & 13,88 & 0,33 & 0,28 & 3678 \\
4. & Kebun pakan & 5,90 & 5,14 & 2,30 & 34,90 & 10,48 & 0,46 & 0,09 & 3826 \\
5. & Matungkas4 & 8,19 & 15,11 & 3,00 & 27,28 & 12,37 & 0,27 & 0,15 & 3779 \\
6 & Kairagi & 7,94 & 16,58 & 3,13 & 26,05 & 14,27 & 0,44 & 0,37 & 3667 \\
\hline
\end{tabular}

serat kasar 33,76/100g, Ca 0,19/100 g, P o,18/100 g dan GEsebesar $3805 \mathrm{kal} / \mathrm{g}$, namun untuk kandungan lemak rumput australia jauh lebih tinggi dibandingkan rumput Paspalum conjugatum di alam yang hanya 0,54 /10og (Mustari \& Masy'ud, 2001). Dengan demikian dapat disimpulkan bahwa jenis rumput pakan yang diberikan pada anoa memiliki kualitas yang cukup baik serta mampu mencukup kebutuhan hidup anoa di penangkaran Anoa Breeding Centre namun perlu tambahan pakan memenuhi kebutuhan untuk kalsium dan phospor. Jumlah kebutuhan Ca yang besar digunakan anoa untuk pembentukan tulang yang lebih kuat demikian pula dengan kebutuhan phospor. Anoa membutuhkan mineral dalam makanan dan minumnya untuk membantu metabolism tubuhnya, dihabit atalaminya kebutuhan mineral diperoleh anoa dengan mengunjungi kubangan-kubangan bergaram (saltlick).

\section{Upaya Peningkatan DayaDukung}

Dibandingkan ketika musim kemarau ketersediaan rumput pakan untuk satwa ruminansiayang dipelihara seperti sapi dan kuda di kota Manado dan sekitarnya mengalami penurunan produktivitas dan menjadi sulit untuk dicari. Penangkaran Anoa Breeding Centre saat ini masih mengandalkan rumput lapangan dalam memenuhi kebutuhan pakan anoa setiap harinya. Berdasarkan hasil penelitian menunjukkan bahwa produktivitas rumput lapangan pada musim kering hanya dapat memenuhi kebutuhan untuk 3-4 ekor anoa/hari, sehingga untuk memenuhi jumlah populasi yang ada dilakukan dengan mencari lokasi-lokasi lain yang dapat menyediakan rumput meskipun lokasi tersebut cukup jauh dari lokasi penangkaran. Alternatif lainnya adalah dengan memberikan pakan campuran berupa hijauan seperti daun-daunan serta tambahan sayuran. Untuk meningkatkan daya dukung dan efisiensi dapat pula dilakukan dengan memanfaatkan areal kosong untuk ditanami dengan rumput jenis unggul.

Pakan alternatif untuk yang diberikan pada anoa di Kebun Binatang Ragunan di Jakarta terdiri atas sayuran dan buah-buahan seperti jagung muda, ubi jalar, kangkung, pepaya, jambu biji, pisang, ketimun, buncis, wortel, kacang panjang, dan rumput (Nurwidyarini, 2009). Sedangkan di penangkaran Anoa Breeding
Centre, jenis pakan alternative yang diberikan pada anoa tidak jauh berbeda seperti umbi, pisang, pepaya, kacang panjang, buncis, serta beberapa hijauan lain yang ada di sekitar kandang yang disukai anoa sepert daun kayu kambing (Garuga floribunda), daun tali utan (Merremia peltata) yang memiliki kandungan Ca cukup tinggi, daun gamal (Gliricidia sepium), turi (Sesbania glandiflora), batang jagung, buah-buah beringin seperti tagalolo (Ficus septica), Nyawai (F. variegata). Hijauan alternatif lain seperti daun kayu kambing dan tali utan sangat baik diberikan pada anoa sebagai pakan namun ketersediaannya di sekitar penangkaran tidak sebanyak rumput pakan. Sehingga pakan-pakan tersebut dapat diberikan secara bersamasama dengan rumput. Sejalan dengan pendapat Mustari dan Mas'yud (2001) yang menjelaskan bahwa pemberian makanan hijauan campuran ternyata lebih baik dibandingkan makanan tunggal dalam hal pemenuhan kebutuhan protein dikarenakan ada sifat efek melengkapi (complementary effect) dari bahan makanan atau zat makanan dalam memenuhi kebutuhan satwa.

\section{KESIMPULAN}

Kebutuhan pakan anoa di penangkaran mengandalkan dari rumput lapangan yang ada di sekitar penangkaran. Ketersediaan rumput pakan pada musim kemarau mengalami penurunan dan sulit dicari. Pengukuran produktivitas pakan enam lokasi menunjukkan hanya $34,15 \mathrm{~kg} / \mathrm{hari}$ dan dapat mencukupi kebutuhan 3-4 anoa perharinya. Sehingga perlu dilakukan peningkatan daya dukung melalui penanaman pada areal kosong sekitar penangkaran dengan rumput unggul atau hijauan lainnya. Kualitas rumput pakan yang diberikan dapat memenuhi kebutuhan protein perhari anoa namun kebutuhan kalsium (Ca) dan phosphor (P) masih belum dapat terpenuhi.

\section{UCAPAN TERIMAKASIH}

terima kasih dipersembahkan kepada temanteman teknisi Yermias Kafiar, Melkianus S. Diwidan Nurasmadi Ostim serta peneliti di Balai Penelitian dan Pengembangan Lingkungan Hidup dan kehutanan 
(BP2LHK) Manado atas tenaga dan kerjasama yang baik dari proses pengambilan data hingga tersusunnya makalah ini.

\section{REFERENSI}

Alikodra, H.S. 2002. Pengelolaan Satwa Liar. Cetakan pertama. Jilid I. Fakultas Kehutanan IPB:Bogor.

Basri, M. 2008. Respon Anoa Gunung (Bubalus quarlesi) terhadap Manipulasi Pakan pada Kondisi Pra budidaya. Jurnal Agroland 15(3):241-250.

Basri,M., dan Rukmi. 2011. Jenisdan Kandungan Tanin Pakan Satwa Anoa (Bubalus sp.). http:://medpet. journal.ipb.ac.id/.Diunduh 4 Juli 2016.

Basri,M., Toharmat, T., \& Alikodra, H.S. 2008. Preferensi Pakan dan Kebutuhan Nutrien Anoa Gunung (Bubalus quarlesi Ouwens 1910) pada Kondisi Pra budidaya. Media Peternakan, 31(1), $53-62$.

Kasim, K. 2002. Potensi Anoa (Bubalus depresicornis dan Bubalus quarlesi) sebagai satwa alternatif budidaya dalam mengatasi kepunahannya. Thesis. Sekolah Pasca Sarjana. Institut Pertanian Bogor, Bogor.

Kushartono, B dan N. Iriani. 2004. Inventarisasi Keanekaragaman Pakan Hijauan Guna Mendukung Sumber Pakan Ruminansia. Prosiding Temu Teknis Nasional Fungsional Pertanian 2004 Hal. 66-71. Pusat Penelitian dan Pengembangan Peternakan.

Kwatrina, R.T.,M. Takandjandji dan M. Bismark. 2011. Ketersediaan Tumbuhan Pakan dan Daya Dukung Habitat Rusa timorensis de Blainville, 1822 di Kawasan Hutan Penelitian Dramaga. Buletin Plasma Nutfah 17(2):129-137.
Mustari, A. H., \& Masy'ud, B. 2001. Kebutuhan Nutrisi Anoa (Bubalus spp.). Media Konservasi, VII (2), 75-80.

Nurwidyarini, W. 2009. Prefrensi dan tingkah laku makan anoa (Bubalus sp.) di Taman Margasatwa Ragunan, Jakarta. Skripsi. Fakultas Peternakan. Institut Pertanian Bogor, Bogor.

Parakkasi, A. 1999. Ilmu Nutrisi dan Makanan Ternak Ruminansia. UI Press: Jakarta. Peraturan Menteri Kehutanan No.54 Tahun 2013 Tentang Rencana dan Aksi Konservasi Anoa Dataran (Bubalus depressicornis dan Bubalus quarlesi).

Pujianingsih, R.I., B. Sukamto., and E. Labiro. 2005. Identification and feed technology processing for roughage in term of Anoa (Bubalus sp.). National Seminar of Fundamental Research. Jakarta, 16$18^{\text {th }}$ May 2005.

Rosyidi, R. 2005. Beberapa aspek biologi dan karakteristik karkas kancil (Ragulus javanicus). Disertasi. Program Pasca Sarjana. Institut Pertanian Bogor, Bogor.

Semiadi, G., Burton, J., Schreiber, A. \& Mustari, A.H. 2008a. Bubalus quarlesi. The IUCN Red Listof Threatened Species 2008:e.T3128A9613851. http://dx.doi.org/10.2305/IUCN.UK.2008. RLTS.T3128A9613851.en. Downloaded on 30 June 2016.

. 2008b. Bubalus depressicornis. The IUCN Red List of Threatened Species 2008: e.T3126A9611738. http://dx.doi.org/10.2305/ IUCN.UK.2008.RLTS.T3126A9611738.en. Downloaded on 30 June 2016.

Susetyo, S. 1980. Padang Penggembalaan. Bogor. Fakultas Peternakan, Institut Pertanian Bogor. 